\title{
Jenő Hubay and His Four Violin Concertos
}

\author{
Lihua $\mathrm{Pu}^{1, *}$ \\ ${ }^{1}$ China West Normal University, School of Music, No.1 Shida Road, Nanchon, Sichuan 637002, PR China \\ *Corresponding author.Email: pulihua@hotmail.com.
}

\begin{abstract}
This paper examines the four Violin Concertos composed by Jenö Hubay. The goal is to present evidence that connections exist between Hubay's style and the performance styles of each of his dedicatees. In addition, his roles as founder of a Hungarian violin school and as a popular concerto soloist will be considered. Hubay's violin concertos have been a neglected area of the repertoire, save for performances and recordings by a few contemporary artists. It is hoped that this study will inspire a continuing interest in the study and performance of these works for both the present and future generations, and also encourage further studies in styles of the Hungarian violin school, and increase appreciation for the important contributions to the violin repertoire by Jenő Hubay.
\end{abstract}

Keywords: Jenö Hubay, Violin Technique, Dedicatees, Violin Concerto, Music Performance

\section{INTRODUCTION}

Jenő Hubay (1858-1937) was a celebrated Hungarian concert violinist, teacher, and composer. Even though he was considered by musicians such as Liszt and Vieuxtemps to be as important as Ysaÿe, his compositions are not as popular today as those of Ysaÿe, and Hubay is greatly underestimated, notably as a composer. The available scholarly research only focusses on his teaching methods in regards Hubay as the founder of Hungarian violin school and does not address his compositional work.

This paper will present a survey of Hubay's four violin concertos, composed at various periods in his life. This paper will introduce the structure and form of the concertos, and include brief discussions of each concerto's style relative to its dedicatees in Chapters 2 and 3. This thesis makes the claim that to present evidence that connections exist between Hubay's style and the performance styles of each of his dedicatees. It is my hope that this project will provide an important performance guide for performers and teachers, and offer insights into Hubay's methods and music.

\section{SUMMARY OF THE LIFE AND VIOLIN WORKS OF JENÖ HUBAY}

The violinist and composer Jenö Hubay (born Huber; 1858-1937), was born in Pest, Hungary. His very first violin teacher was his father, Károly Huber. Károly was a successful professional musician who had been concertmaster of the Hungarian National Theater. Beginning at age thirteen, Hubay studied for five years with the noted violinist Joseph Joachim. Thus, from the very beginning, Hubay received first-class training; in 1879, he adopted the Hungarian version of his last name, becoming Jenő Hubay [1], paving the way for his eventual career as a performer of exceptional stature [2].

During his lifetime, Hubay was very popular with the European public, giving concert tours for twenty-five years beginning in 1880 [3]. This popularity, however, did not extend to his colleagues. Charles Castleman suggests that Hubay was disliked for three reasons, the first being Joachim's opposition to Liszt, who was one of Hubay's important mentors in his later career; scholar Alan Walker explains that Joachim represented the 'conservative' force of the nineteenth century, who wanted to preserve and perpetuate the forms handed down by the Viennese classicists against the progressives, like Liszt, who wanted to modify and expand them. This might be explained by Joachim's admiration of Brahms, so they may have been an expectation that his pupil would follow Brahms, not Liszt. However, Hubay had come under the influence of Liszt and the progressives after his return to Budapest. The second reason was Eugène Ysaÿe, who would neither forgive nor forget losing the professorship at the Brussels Conservatory to Hubay. The third and possibly the most important reason was on account of Hubay's royalist ties in the face of the Communist regime which took power in Hungary following World War I [2]. According to Gombos, "the palace on the banks of the Danube and other estates 
caused him increased concern. Hubay fled with his family to Switzerland after the communist take-over. His work as a composer became increasing difficult, and he produced no significant new works in the 1920s" [4].

Liszt, together with Wieniawski and Vieuxtemps, all played an important role in Hubay's development as an artist and performer. Gombos believes that Liszt made "decisive influences on the formation of Hubay's musical style when he [Hubay] turned his attention increasingly towards large-scale genres" [3]. The influence can be traced to Liszt's support for Hubay, beginning early in Hubay's career. Their relationship began in 1876 , as a twenty-year old Hubay frequently performed with Liszt in duo-recitals on many important occasions in Budapest [2]. In addition Hubay went to Paris, on Liszt's advice, in May 1878 to upgrade his musical skills [4]. The Paris period is considered the starting point of Hubay's mature musician's life, having come to Paris with considerable celebrity from his earlier performances with Liszt; according to Gombos, "He had huge success as soloist [from Hungary]" [4]. This was also the time when he changed his surname to Hubay, giving it a more Hungarian-sounding quality. The Paris period reveals Hubay's awareness as an ethnic Hungarian. Hubay was welcomed by Vieuxtemps and became a frequent guest in Vieuxtemps's house [4]. Moreover, Liszt had also introduced Hubay to Henryk Wieniawski after the duo's performance on 25 February, 1877 in Budapest [4], and due to Liszt's generosity and support, along with Hubay's own efforts and abilities, Hubay succeeded Wieniawski as principal violin professor at the Brussels Conservatoire in 1882 [2]. Gombos says: “A milestone in Hubay's career was when Vieuxtemps suggested his name as Professor of Violin at the Brussels Conservatoire" [2]. In 1886, Hubay went back to Hungary to teach at the Academy of Budapest, and established his own violin studio [2].

Hubay became a popular violin soloist in Europe following his performances in Paris. Much of the biographical information on Hubay, however, concerns his role as a teacher. He is said to have founded one of the world's great violin schools [2] - the Hungarian violin school. His pupils, including Jozsef Szigeti, Ferenc Vecsey, and Stefi Geyer, all gained a level of celebrity equal to that of their teacher. Hubay composed his four violin concertos while he had the violin professor position at the Brussels Conservatoire and the Academy of Budapest between 1882 and 1936 [3].

During his life, Hubay composed more than two hundred individual works employing solo violin [4]. According to Gombos, many of Hubay's compositions reveal a very strong Hungarian nationalism, in both choice of libretto (such as in his stage works The Village Rascal and Lavotta's Sweetheart) and the use of folk songs, along with the "verbunkos" style in the music. Verbunkos is a Hungarian dance. According to Lujza Tari, verbunkos became popular in West European art music, which incorporated elements of it. She states that this process implies "the use of melodic schemes, rhythms, rhapsodic performance and other performing mannerisms deemed typical of Hungarian or Gypsy music, to the involvement of the solo violin as the leading instrument of a performing apparatus" [5]. From Tari's research on "verbunkos" styles, it can be seen that Hubay exhibits similar traits of this style in his violin concertos. One of the characteristics of the "verbunkos" style is sharply emphasized dotted rhythms in 4/4 time, which can also be observed in Hubays' violin concertos. Another of the characteristics of verkunbos is the "freely shaped rhapsodic elements" in slow sections, contrasting with vivid, virtuoso motifs in fast sections, which can be seen in the Hubay concertos as well. The influence of the "verbunkos" style on Hungarian music in general cannot be underestimated; Liszt himself proposed that a course in Hungarian composition be a required part of the curriculum at the Academy of Music in Budapest [6]. As mentioned above, as per Hubay's relationship with Liszt, I suggest that Liszt himself may have been a powerful influence in evoking the Hungarian nationalism in Hubay's works. Interestingly enough, not only are each of the concertos dedicated to a violin virtuoso who was famous in his/her own right, but three out of four dedicatees were also Hungarians, and all had a close relationship with Hubay.

\section{STYLISTIC RELATIONSHIP: THE CONCERTOS AND THEIR DEDICATES}

Before Hubay settled in Budapest in 1886, he was a travelling virtuoso and composer. Gombos indicates that many of Hubay's concert renditions of other composers' works, such as Strauss's Blue Danube Waltz and Liszt's Rhapsody No.12, did not correspond to the printed versions [4], and were subject to improvisation and variation during his performances. Henry Roth describes the style of Hubay's Hungarian school as, "strongly influenced by the old Belgian school of Vieuxtemps, [which] stressed virtuosity rather than intellectual force, tonal splendour or modern sophistication" [7]. Hubay's style of performing his and other composers' works during this period demonstrate that his interest in structure and form was secondary to the creation of an outstanding, colorful, and virtuosic performance.

The sequence of Hubay's violin compositions (according to opus number) reveals that the Concerto Dramatique, Op. 21 was his first attempt at the larger form and structure of the concerto after having composed a number of shorter violin concertos, as well as the Konzertstück for viola and orchestra. Like previously mentioned, Hubay composed concertos with more attention to creating a display of virtuoso violin technique than to form. As a result, the first concerto is 
full of improvisatory-like passages, all of which are fully notated.

The dedicatees of Hubay's four violin concertos were all professional violinists and performers with whom he had a special relationship. Joseph Joachim (1831-1907), as mentioned in Chapter 1, was his first teacher after his father; Oscar Studer (1877-1940) was a Swiss violinist and fellow artist; Ferenc Vecsey (1893-1935) and Stefi Geyer (1888-1956) were his own students. The diverse styles found in the concertos suggest that Hubay modeled these works after each dedicatees' personal performing style.

\subsection{Concerto Dramatique Op. 21}

Hubay's First Violin Concerto, Op. 21 in A minor, was composed in 1884-1885, when he was just twentysix years old. A late nineteenth-century composition, it was titled "Concerto Dramatique" and was dedicated to Joseph Joachim. The main concept in the first movement is the free use of solo cadenzas within traditional sonata form. In the first movement of Op. 21, there are two cadenzas; the first one at the very beginning, and the second one at the recapitulation of the solo part.

Interestingly, Hubay later performed this piece himself at a concert celebrating his $50^{\text {th }}$ birthday, while some of his students played the other three concertos. I suggest that, in addition to writing with Joachim in mind, Hubay composed such a difficult piece in part to showcase his own phenomenal violin skills and technique.

Hubay studied with Joseph Joachim from the autumn of 1873 to the spring of 1876 [4]. As Joachim's student, Hubay was encouraged to perform in public, and Joachim would perform with him to help Hubay gain more public attention [4]. Many scholars have noted Joachim's inclination was to infuse a composer's work with a big and rounded sound [8]. Journalist and Haydn scholar, Marian M. Scott describes Joachim's fondness for creating effects in the high register of the E string "as in the opening solo of Beethoven's concerto" [9] and I suggest Hubay may have had this in mind when composing the first concerto for Joachim. In the first movement of Op. 21, the soloist enters with an improvisatory-like passage, introducing the a tempo (m.27), in the $8^{\text {th }}$ register of the E string. Joachim's affinity for the $\mathrm{E}$ string can been seen even more prominently in the second movement, where threequarters of the melody appears in the high register of the E string.

In regards to tone quality, London reviewer H.P. Morgan-Brown described Joachim's tendency to a "glassiness in tone" [10] and Hubay may have intended to reflect this quality in his writing for Joachim by consistent use of harmonics. At the soloist's entrance at $\mathrm{m} .56$, approximately half of the notes are indicated in natural harmonics (see Figure 1 below). Moreover, natural harmonics figure prominently throughout Op. 21, both in statements of the main themes and in transitional passages.

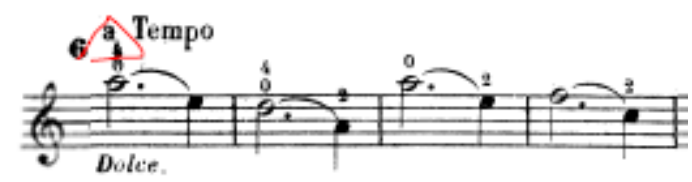

Figure 1 Hubay, Concerto Dramatique Op. 21/I, mm.56-59.

Scholars who heard Joachim's performances usually regarded him as one of the greatest virtuosos of his time. Critic Eduard Hanslick noted Joachim's Vienna tour of 1867: "Joachim is the living incarnation of the most exceptional, artistic and spiritual virtuosity. Technically, he is so near to absolute perfection that we are scarcely capable of detecting the imperceptible difference which separates him from it" [8]. Several passages from the fourth movement of Op. 21 demonstrate that Hubay could write music that capitalized on Joachim's extraordinary technique. Examples may be seen at the soloist's introduction, particularly at $\mathrm{mm}$. 46-62, primarly built in double-stopped octave scales. Another example appears at mm. 339-375 (see Figure 2 below), which features a technically demanding sequence of triple-stopped chords, while maintaining a short-bowing. Also, this passage is interspersed with natural and artificial harmonics which is also a tip of the hat to Joachim's style.

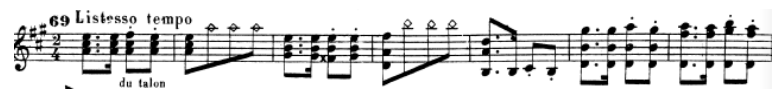

Figure 2 Hubay, Concerto Dramatique Op. 21/I, mm.339-345.

\subsection{2ème Concerto pour Violon (no. 2, in $E$ Major), Op. 90}

The Second Violin Concerto, Op. 90 in E major, was composed at the turn of the century (in 1900) and was dedicated to Hubay's younger colleague, Oscar Studer. This was during the time Hubay had settled in Budapest, where he worked as a violin professor at the Budapest Academy of Music. In contrast to the first concerto, the first movement of the second concerto does not have a cadenza; instead, various technical difficulties are distributed throughout the work, including triplet figurations, sequences of shifting tonalities, and arpeggios. The second movement is Larghetto, and begins with a Romantic, song-like theme, followed by improvisatory variations, and Hubay adds another technical difficulty by placing the recapitulation of the main theme in a high register. The last movement is Allegro non troppo, its opening dance-like theme also demanding a high level of technique from the soloist. 
Oscar Studer, who was the dedicatee of the second concerto is a Swiss violinist. An online biography of Hungarian violinist Gyorgy Garay discusses the relationship between Studer and Hubay [11]. Garay's history suggests that Hubay maintained a close relationship with Studer, and that Garay himself possibly went to Hubay's studio on Studer's recommendation. The second concerto reflects a much simpler style than that of Op. 21, yet nevertheless, it is virtuosic, befitting Studer's reputation as a high-level virtuoso performer; Studer performed the second concerto with the Leipzig Gewandhaus, under Artur Nikisch [12].

According to the article, besides teaching at Budapest, Studer enjoyed the role as a performer in the field of chamber music, with his founding the "Hungarian Trio" in 1902 [12]; In fact, Studer was celebrated as much as a chamber musician as he was a virtuoso soloist. Hubay's writing for Studer suggests that this concerto is more focused on the beauty of the melodic line than on technical challenges, with a balanced structure, clear metrical indications, and an abundance of lyrical melodies, particularly in the second movement. In contrast with Op. 21, there is infrequent use of doublestops or chords, which appear in less than ten measures in all of Op. 90. Another aspect is that there are no indicated ad libitum passages at all. There are still some metrical passages requiring tempo rubato and allowing the flexibility in the use of portamento in the soloist's line, or in unaccompanied passages.

\subsection{3ème Concerto pour Violon avec accompagnement d'Orchestre, Op. 99}

The Third Concerto, Op. 99, is in G minor, and was composed and dedicated à son cher Ferenc Vecsey(18931935), a young violin virtuoso in 1906. Compared to the previous concertos, this concerto might be viewed as being more musically mature. For example, Hubay uses the same techniques as in the earlier concertos: arpeggios, shifting, trills, and fast changes of triplets and dottedsixteenth notes, but in this concerto, he places them gracefully within the phrases to serve the melodic line rather than simply to create technical difficulties. At the same time, he adds more double stops and chords as a challenge for the violinist.

Vecsey was a child prodigy who began studying with Hubay at the age of eight and was considered the leading exponent of Hubay's Hungarian violin school. Henry Roth describes the style of Hubay's Hungarian school as "strongly influenced by the old Belgian school of Vieuxtemps, [which] stressed virtuosity rather than intellectual force, tonal splendour or modern sophistication" [7] and also cites Vecsey as a leading exponent of this school. The scholar recalls a 1904 recording by Vecsey, which reveals a "technician of amazing facility and verve" [7]. In addition, Roth provides an overall account of Vecsey's style based on a large number of recordings. He notes that:

his tone is capable of genial warmth, particularly on the G-string, and his fairly well-developed vibrato is used with an awareness considerably beyond the world of Sarasate, Joachim and Kubelik. Yet, often his playing is cool and dry, heavy-handed, and at times, downright crude [7].

Joachim credited Vecsey's technique to Hubay's training; Joachim himself marveled at Vecsey's playing, and "considered him to be the most gifted violinist of the era" [11]. I suggest that the cadenza in the fourth movement of Op. 99, one of the primary technical challenges of this work, exemplifies the relationship between the composer and the dedicatee. Op. 99 marks the first appearance of a large written-out cadenza in the printed versions of Hubay's concertos, and Hubay may have created this cadenza based on Vecsey's own repertoire. The Musical Times article of 1904 on Vecsey records that "Paganini pieces added to his repertoire before he was eight years old" [11], and several passages of the cadenza clearly recall the Paganini Caprices.

The cadenza contains only a few variations, but Hubay added specific indications to divide them by tempo and style (i.e., Vivo, Allegro, Scherzando, etc.) where there is no meter or bar line. The cadenza is based on materials and motives from the previous three movements. Almost every virtuosic technique is utilized: a sequence of descending pitches with grace notes a sixth or seventh lower (at the beginning); Bachian figurations, with double and triple stops (Vivo and tranquillo sections); thirty-second note arpeggios (recalling the Paganini First Caprice); triple stops, with octaves over an open string (3/4 section); a motive leaping between notes from the lowest register of the $G$ string to the highest register of the E string; and so on. As the principal teacher of Vecsey, Hubay undoubtedly recognized his student's capabilities, and was perhaps attempting to exceed the difficulties of the Paganini caprices to show off Vecsey's capabilities on the violin.

\subsection{Concerto all'antica, Op. 101}

The Fourth Concerto, All'Antica (no. 4), Op. 101, in A minor, was written and dedicated to the violin virtuoso Stefi Geyer, in 1906-07. The fourth concerto is shorter than the third, the structure of the piece is tighter, and the phrasing and technical patterns change frequently. The last two concertos were both composed in 1906. Since there are, at present, no existing analyses for any of these violin concertos, the primary sources for this project are the scores published by Henry Lemoine, Hamelle and J.H. Zimmermann, which were printed during Hubay's lifetime.

Mademoiselle Stefi Geyer, a child prodigy who also studied with Hubay from an early age. Critics reported 
her United States debut at Town Hall, New York, in 1924, as displaying "a firm, generally smooth tone, a confident, vigorous style with emphatic bowing and a welldeveloped, thoroughly competent, technique" [13].

A program which Geyer had given in the United States in December of 1924 included “. . . Louis Spohr's No.8- Gezangsszene, Bach's Chaconne, short pieces by Beger, Hubay and Vieuxtemps, and arrangements by Tartini and Kreisler" [14], displaying her inclination for Romantic, virtuoso pieces. Geyer's abilities over a wide range of repertoire and secure technique were the inspiration behind Bartok's First Violin Concerto, and Othmar Schoeck's Violin Concerto in B Flat Major, Op. 21 [15], and both works are dedicated to her. Hubay composed Op. 101 with her performance style in mind, incorporating high technical demands and a virtuoso Romantic quality which figures prominently throughout the concerto. Most noticeable are the frequent changes of texture and dynamics; such as quadruple-stop $f f$ chords, followed by dolce passages in a single-voiced, $p$ line. Furthermore, as the only female figure among the four dedicatees, I suggest the character of the second movement evokes the image of a lovely young girl who is a talented violinist, and presents as a spiritual model for many composers, whereas the mixed pizzicato and spiccato, with a tempo of Presto, convey a young girl's nature [see Figure 3 below]. This character is unique among Hubay's concertos.

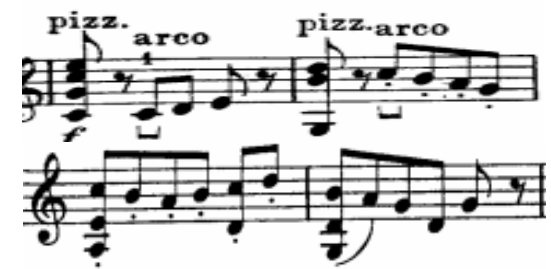

Figure 3 Hubay, Concerto All'Antica, Op. 101/II, mm. 17-19.

\section{CONCLUSION}

As of this writing, there is no published pedagogical material available to assist performers in the study and performance of Jenő Hubay's four violin concertos. This study provides a new approach to preparing and interpreting these concertos, by first examining the form of each concerto, followed by a study of the performance styles of the dedicatees.

in the violin concertos, Hubay allows for (and expects) a certain degree of freedom from the performer, but this freedom must be gauged by understanding the individual styles of the dedicatees, which must then be combined with the ability to interpret passages in a score where indications are not given.

As noted above, all of the dedicatees had a special relationship to Hubay: Joachim was one of his teachers; Studer was a professional colleague; Vecsey and Geyer were his students, and all had evolved as child prodigies, each developing into a virtuoso with specific inclinations. Joachim had a highly virtuosic style, with a preference for the E-string; Studer, while a virtuoso, was given to a more intimate style of playing, which may be a reflection of his extensive work as a chamber musician; Vecsey's wide and virtuosic repertoire allowed for the incorporation of stylistic effects derived from composers such as Bach and Paganini; Geyer combined a wide, engaging repertoire with a powerful stage personality. Once one understands these respective styles, one can then unite them to the demands and styles of each concerto.

The importance of this study lies in its pedagogical value, creating an informed perspective for approaching, understanding, and preparing these concertos for a convincing performance.

Hubay's violin concertos have been a neglected area of the repertoire, save for performances and recordings by a few contemporary artists. It is hoped that this study will inspire a continuing interest in the study and performance of these works for both the present and future generations, and also encourage further studies in styles of the Hungarian violin school, and increase appreciation for the important contributions to the violin repertoire by Jenő Hubay.

\section{REFERENCES}

[1] Moore, Joseph A. "Prince of the Violin." Classic Record Collector (2009): 10-15.

[2] Castleman, Charles. "The Romantic ViolinistComposer: Pro-active Artist Before a Susceptible Public: A Personal View." In Liber Amicorum Isabelle Cazeaux: Symbols, Parallels and Discoveries in Her Honor, ed. Paul-Andre Bempechar, 349-364. Hillsdale: Pendragon, 2005.

[3] Gombos, László. "Hubay Jenő." In The New Grove Dictionary of Music and Musicians, Edited by Stanley Sadie and J. Tyrrell; vol. p.784. London: Macmillan, 2001.

[4] Gombos, László. Jenő Hubay. Trans. Peter Woodward. Budapest: Magus Publications Ltd, 1998.

[5] TARI, Lujza. "The Verbunkos, a Music Genre and Musical Symbol of Hungary." Bulletin of the Transilvania University of Braşov (2012): 83.

[6] Legány, Dezső. “Liszt and Erkel's Relations and Students." Studia Musicologica Academiae Scientiarum Hungaricae (1976): 19-50.

[7] Roth, Henry. "The Man Time Left Behind." The Strad (1993): 1033 . 
[8] Stoll, Barrett. "Joseph Joachim: Violinist, Pedagogue, and Composer." $\mathrm{PhD}$ dissertation,University of Iowa, 1978.

[9] Scott, Marian M. "Joseph Joachim." The Monthly Musical Record, vol.213, No. 726 (1931): 162.

[10] Morgan-Brown, H.P., "Wilhelmj, Joachim, Sarasate and Ysaye," The Strad, vol. XXXV, No. 416 (1924): 492.

[11] Author Unknown. "Franz von Vecsey." The Musical Times, Vol.45, No. 736 (1904): 379.

[12] Szende, Otto. "Oskar Studer (1877-1940): un important collaborateur Suisse de l'école de violin hongroise Hubay (An Important Swiss collaborator in the Hubay Hungarian violin school)." Schweizer musikpadagogische Blatter/Cashiers suisses de pedagogie musicale (1991): 159-162.

[13] Author Unknown. "Stefi Geyer, Violinist, In Debut at Town Hall: Soloist on Stringed Instruments Lead Recitals; Ernest Daris, Tenor, Sings.” The New York Herald, New York Tribune (1924): 16.

[14] Author Unknown. "Stefi Geyer Plays Again: Violinist Pleases in Her Second Recital at Town Hall." The New York Herald, New York Tribune (1924): 24.

[15] Schoeck, Othmar. Violin Concerto in B-Flat Major, Op.21. Leipzig/Zurich: Gebrüder Hug Co, 1912. 